\section{Meningkatkan Aktivitas, Motivasi dan Hasil Belajar Melalui Penerapan Model Problem Based Learning pada Siswa Kelas XI MIPA 1 MAN Enrekang}

\author{
Nurfadillah \\ Mushawwir Taiyeb \\ Syamsiah
}

\begin{abstract}
Abstrak: Penelitian ini bertujuan untuk mengetahui peningkatan aktivitas, motivasi dan hasil belajar siswa melalui penerapan model Problem Based Learning (PBL) pada siswa kelas XI MIPA 1 MAN Enrekang pada materi sel. Jenis penelitian ini adalah penelitian tindakan kelas (PTK) yang terdiri dari 2 siklus. Subjek dalam penelitian ini adalah siswa kelas XI MIPA 1 MAN Enrekang. Jenis instrumen penelitian yang digunakan adalah lembar observasi aktivitas belajar, angket motivasi belajar dan tes hasil belajar dalam bentuk tes pilihan ganda sebanyak 20 butir untuk setiap siklus pada materi sel. Data yang diperoleh dianalisis secara statistik deskriptif. Hasil penelitian menunjukkan bahwa (1) terjadi peningkatan aktivitas belajar biologi siswa kelas XI MIPA 1 MAN Enrekang yaitu secara klasikal dari 66,47\% meningkat menjadi 80,03\%, jumlah peningkatan dari siklus I ke siklus II adalah 13,56\%; (2) terjadi peningkatan motivasi belajar biologi siswa kelas XI MIPA 1 MAN Enrekang yaitu secara klasikal dari 82,87\% meningkat menjadi 86,97\%, jumlah peningkatan dari siklus I ke siklus II adalah 4,11\%; (3) terjadi peningkatan hasil belajar biologi siswa kelas XI MIPA 1 MAN Enrekang yaitu dari 59,38\% siswa yang tuntas menjadi 96,88\%, jumlah peningkatan dari siklus I ke siklus II adalah 37,50\%. Hasil ini menunjukkan bahwa penerapan model Problem Based Learning dapat meningkatkan aktivitas, motivasi dan hasil belajar siswa kelas XI MIPA 1 MAN Enrekang.
\end{abstract}

Kata Kunci: Problem Based Learning, aktivitas, motivasi dan hasil belajar.

\section{Pendahuluan}

Hak setiap warga negara adalah mendapatkan pendidikan menurut undang-undang dasar 1945 pasal 31 ayat 1 , amanat yang terkandung dalam pasal tersebut adalah mendapatkan pendidikan merupakan hak setiap individu tanpa memandang latar belakang individu tersebut (Undangundang dasar 1945 pasal 31 ayat 1 tentang pendidikan dan kebudayaan). Manusia yang cerdas, berakhlak dan berkepribadian diharapkan mampu dicetak melalui proses pendidikan untuk melahirkan generasi yang memiliki sumber daya manusia yang handal, kompetitif, dan kompetibel yang dapat mengangkat harkat dan martabat bangsa Indonesia di mata dunia. Daoed (2009) menyatakan bahwa pendidikan merupakan alat yang menentukan untuk mencapai kemajuan dalam segala bidang penghidupandalam memilih dan membina hidup yang baik sesuai dengan martabat manusia. Amrullah (2016) mengemukakan bahwa pengetahuan yang dimiliki siswa merupakan hasil yang diperoleh melalui proses pembelajaran dan diukur dari hasil belajar. Hasil belajar digunakan oleh guru untuk dijadikan kriteria atau ukuran dalam mencapai suatu tujuan pendidikan sehingga diharapkan nantinya akan menghasilkan mutu pendidikan

\section{Biology Teaching and Learning}

p-ISSN $2621-5527$

e-ISSN 2621 - 5535

Abstract: This study aims to determine the increase in activity, motivation and student learning outcomes through the application of the model Problem Based Learning (PBL) in class XI MIPA 1 MAN Enrekang on cell material. This type of research is a classroom action research (CAR) which consists of 2 cycles. The subjects in this study were students of class XI MIPA 1 MAN

Enrekang. The type of research instrument used was a learning activity observation sheet, a learning motivation questionnaire and a learning outcome test in the form of multiple-choice tests of 20 items for each cycle of cell material. The data obtained were analyzed statistically descriptive. The results showed that (1) there was an increase in the biology learning activities of students in class XI MIPA 1 MAN Enrekang namely classically from $66.47 \%$ increased to $80.03 \%$, the amount of increase from cycle I to cycle II was $13.56 \%$; (2) an increase in biology learning motivation of students in class XI MIPA 1 MAN Enrekang that is classically from $82.87 \%$ to $86.97 \%$, the amount of increase from cycle I to cycle II is 4.11\%; (3) an increase in biology learning outcomes of students in class XI MIPA 1 MAN Enrekang namely from $59.38 \%$ of students who completed to $96.88 \%$, the number of increases from

cycle I to cycle II was $37.50 \%$. These results indicate that the application of the Problem Based Learning model can

improve the activity, motivation and learning outcomes of students of the XI MIPA 1 MAN class Enrekang.

Keywords: Problem Based Learning, activity, motivation and learning outcomes

Nurfadillah

Universitas Negeri Makassar Indonesia

Mushawwir Taiyeb

Universitas Negeri Makassar Indonesia Syamsiah

Universitas Negeri Makassar Indonesia 
yang baik. Banyak faktor yang menyebabkan mutu pendidikan tidak mengalami peningkatan yang bermakna, salah satunya adalah pendekatan yang digunakan dalam kelas belum mampu menciptakan kondisi optimal bagi berlangsungnya pembelajaran. Selama ini pendekatan yang digunakan adalah pendekatan yang menganggap bahwa apabila input pendidikan seperti pelatihan guru, pengadaan buku dan alat pelajaran, dan perbaikan sarana dan prasarana pendidikan lainnya dipenuhi, maka peningkatan mutu pendidikan (output) secara otomatis akan terjadi. Namun dalam kenyataannya peningkatan mutu pendidikan yang diharapkan tidak terjadi, pendekatan terlalu memusatkan pada inputdan kurang memperhatikan proses pendidikan, padahalproses pendidikan sangat menentukan output pendidikan (Depdiknas, 2001).

Trianto (2010) mengemukakan bahwa proses pembelajaran sains termasuk biologi mestinya menekankan pada pemberian pengalaman langsung kepada siswa sehingga siswa memperoleh pemahaman mendalam tentang alam sekitar dan prospek pengembangan lebih lanjut dapat menerapkannya di dalam kehidupan kehidupan sehari-hari.

Pembelajaran sains di sekolah seharusnya melibatkan aspek sikap, proses, produk, dan aplikasi, sehingga siswa dapat mengalami proses pembelajaran secara utuh, memahami fenomena alam melalui kegiatan pemecahan masalah, metode ilmiah, dan meniru kerja ilmuan dalam menemukan fakta baru. Kecenderungan pembelajaran sains saat ini, siswa hanya mempelajari sains sebagai produk, menghafalkan konsep, teori dan hukum, serta berorientasi pada hafalan. Akibatnya, sikap, proses, dan aplikasi tidak tersentuh dalam pembelajaran. Pengalaman belajar yang diperoleh di kelas tidak utuh dan tidak berorientasi tercapainya standar kompetensi dan kompetensi dasar (Trianto, 2010).

Hasil observasi mengungkapkan masalah utama dalam pembelajaran di kelas XI Matematika dan Ilmu Pengetahuan Alam (MIPA) 1 Madrasah Aliyah Negeri (MAN) Enrekang adalah masih rendahnya hasil belajar siswa. Hal ini tampak dari rata-rata hasil ujian per bab materi secara klasikal menunjukkan persentase ketuntasan belajar masih di bawah $75 \%$ yakni hanya sekitar $60 \%$ siswa yang tuntas. Jika merujuk pada pendapat muslich (2007) bahwa ketuntasan belajar ideal untuk setiap indikator adalah $0 \%-100 \%$ dengan batas kriteria ideal minimum 75\%. Wawancara yang dilakukan oleh penulis pada tanggal 5 Maret 2019 dengan Imran, S.Pd, M.Pd guru mata pelajaran biologi kelas XI MIPA MAN Enrekang menyatakan rendahnya hasil belajar siswa di kelas XI MIPA 1 MAN Enrekang diduga disebabkan antara lain karena: (1) rendahnya pemahaman siswa dalam menerima pelajaran yang diberikan oleh guru sehingga siswa sulit menjawab pertanyaan-pertanyaan; (2) aktivitas dan motivasi belajar siswa yang sangat rendah di tandai dengan kurangnya inisiatif siswa untuk mencari informasi terkait materi yang di ajarkan. Mereka cenderung menunggu materi yang diberikan oleh guru tanpa berusaha untuk mengembangkannya secara mandiri; (3) pembelajaran masih berpusat pada guru.

Syah (2010) mengungkapkan salah satu faktor yang mempengaruhi keberhasilan proses dan hasil belajar siswa adalah pendekatan belajar. Pendekatan belajar merupakan jenis upaya belajar siswa yang meliputi strategi yang digunakan siswa untuk melakukan kegiatan dalam mempelajari materi pelajaran. Masalah kepasifan dalam proses pembelajaran dan kurangnya motivasi belajar siswa juga menjadi masalah yang perlu diperhatikan di kelas XI MIPA 1 MAN Enrekang. Tidak dapat dipungkiri bahwa permasalahan ini juga sedikit banyak berpengaruh terhadap hasil belajar yang dicapai oleh siswa-siswa tersebut.

Guru akan mengetahui apakah metode serta media yang digunakan sudah tepat atau belum dari hasil belajar yang diperoleh. Jika sebagian besar siswa memperoleh angka jelek pada penilaian yang diadakan, mungkin hal ini disebabkan oleh pendekatan yang digunakan kurang tepat. Apabila demikian halnya, maka guru harus mawas diri dan mencoba mencari pendekatan dalam mengajar. Hasil belajar juga merupakan cerminan kualitas suatu sekolah (Arikunto, 2005). Pemilihan model pembelajaran yang tepat selain dapat meningkatkan aktivitas siswa di dalam kelas, juga dapat memberikan motivasi serta dapat mengembangkan kemampuan 
intelektual siswa secara optimal, dengan demikian siswa tidak hanya menyerap informasi dari guru, akan tetapi juga dapat memahami konsep materi secara utuh karena adanya interaksi antara siswa dengan guru maupun siswa dengan siswa lainnya (Amrullah, 2016).

Model pembelajaran yang relevan dan sesuai dengan Kurikulum 2013 yang berpusat pada siswa dan mampu untuk meningkatkan aktivitas dan motivasi belajar siswa dalam proses pembelajaran adalah model Problem Based Learning (PBL). Pembelajaran berbasis PBL ini sejalan dengan permintaan pembelajaran yang diinginkan pada Kurikulum 2013. Pembelajaran terfokus pada siswa (student-centered) sehingga segala aktivitas dilakukan oleh siswa dimulai dari siswa menemukan permasalahan nyata berdasarkan kehidupan sehari-hari atau yang ada dilingkungan, kemudian siswa mengumpulkan beberapa permasalahan hingga siswa dapat menyelesaikan suatu permasalahan yang dihadapi.

Kegiatan belajar memecahkan masalah merupakan usaha untuk mengembangkan kemampuan berpikir siswa. Berpikir adalah aktivitas kognitif tingkat tinggi yang melibatkan asimilasi dan akomodasi berbagai pengetahuan dan struktur kognitif yang dimiliki siswa untuk memecahkan suatu masalah (Suprijono, 2012).

Penerapan model Problem Based Learning menurut Sanjaya (2012) dapat meningkatkan aktivitas dan motivasi belajar siswa, selain itu juga membantu siswa untuk mengembangkan pengetahuan barunya dan bertanggung jawab dalam pembelajaran yang mereka lakukan serta dapat memudahkan siswa dalam menguasai konsep-konsep yang telah dipelajari sehingga mampu meningkatkan hasil belajar siswa. Model problem-based learning dapat diterapkan pada hampir semua bidang studi sehingga guru mata pelajaran sains sangat dianjurkan untuk menggunakan model dan strategi mengajar yang berorientasi pada cara pemecahan masalah (Syah, 2013).

Relevan dengan hasil penilitian yang dilakukan oleh Musriadi dan Muhibbudin (2014) menunjukkan bahwa: (1) Kemampuan hasil belajar materi jamur (fungi) menggunakan model problem-based learning lebih baik dibandingkan dengan kemampuan hasil belajar materi jamur (fungi) menggunakan model pembelajaran konvensional. Dengan menggunakan pembelajaran berbasis masalah dapat menjadikan siswa lebih kreatif, berpikir tingkat tinggi dan aktif, (2) Motivasi belajar siswa pada belajar materi jamur (fungi) menggunakan model problem-based learning lebih baik dibandingkan dengan kemampuan hasil belajar materi jamur (fungi) menggunakan model pembelajaran konvensional. Siswa lebih menyukai pembelajaran berbasis masalah karena interaksi-interaksi yang muncul membuat mereka lebih mudah dan cepat dalam memperoleh tujuan belajar. Sikap tertarik yang ditampilkan siswa memberikan motivasi yang tinggi pada proses pembelajaran.

Berdasarkan latar belakang di atas, maka peneliti tertarik untuk melakukan penelitian dengan judul "Penerapan Model Problem Based Learning (PBL) untuk Meningkatkan Aktivitas, Motivasi dan Hasil Belajar Siswa Kelas XI MIPA 1 MAN Enrekang".

\section{Metode Penelitian}

\section{Rancangan Penelitian}

Penelitian ini menggunakan rancangan penelitian tindakan kelas (PTK) yang terdiri atas 2 siklus, setiap siklus terdiri atas 2 kali pertemuan, serta dilakukan tes di setiap akhir siklus.

\section{Waktu Penelitian}

Penelitian ini dilaksanakan pada bulan Juli 2019 di MAN Enrekang yang berlokasi di Jl. Pemuda No. 31A Kelurahan Tomenawa Kecamatan Baraka Kabupaten Enrekang dengan subjek penelitian yaitu siswa kelas XI MIPA 1 MAN Enrekang dengan jumlah siswa terdiri dari 32 orang. Penelitian ini menggunakan model spiral dari Kemmis dan McTaggart yang merupakan model 
yang dikembangkan oleh Kurt Lewin. Penelitian ini dilaksanakan bersiklus dengan setiap siklusnya terdiri dari tahapan-tahapan yaitu: perencanaan, pelaksanaan tindakan, pengamatan, dan refleksi. Pada Model Kemmis dan McTaggart, sesudah siklus selesai diimplementasikan kemudian diikuti dengan adanya perencanaan ulang yang dilaksanakan dalam bentuk siklus tersendiri demikian seterusnya (Pujiono, 2008).

\section{Instrumen Penelitian}

Instrumen yang digunakan dalam penelitian ini adalah: (1) Lembar observasi untuk mengukur aktivitas siswa dalam proses belajar mengajar yang meliputi: keaktifan siswa dalam menyimak dan mencatat topik dan tujuan pembelajaran, menjawab pertanyaan guru, keaktifan siswa dalam menyimak penyampaian materi, memikirkan masalah yang diberikan, diskusi kelompok, presentasi kelompok, mengajukan pertanyaan, menjawab pertanyaan siswa, penarikan kesimpulan dari materi pelajaran, mengerjakan tugas yang diberikan; (2) Angket motivasi yang digunakan adalah model skala likert. sebelum instrumen ini digunakan oleh peneliti, diawali dengan proses validasi oleh validator ahli. Angket motivasi ini terdiri dari 19 item pernyataan yang diberikan kepada siswa pada akhir siklus. Setiap item yang digunakan di dalam instrumen terdiri dari sangat setuju (SS), setuju (S), kurang setuju (KS), tidak setuju (TS), sangat tidak setuju (STS) yang diadaptasi dari Uno (2012); (3) Tes hasil belajar dalam bentuk pilihan ganda, sebanyak 20 butir soal untuk setiap siklus; (4) Perangkat pembelajaran yang digunakan dalam penelitian ini berupa silabus yang dimodifikasi oleh peneliti, rencana program pembelajaran (RPP), dan lembar kerja peserta didik (LKPD).

Penelitian Tindakan Kelas (Classroomaction research) diawali dengan refleksi awal yang dilakukan oleh peneliti yang berkolaborasi dengan partisipan mencari informasi lain untuk mengenali dan mengetahui kondisi awal atau mencari masalah yang ada pada tempat yang akan dijadikan subjek penelitian. Secara umum penelitian tindakan kelas memiliki desain dengan empat langkah utama, yaitu perencanaan, tindakan, observasi/evaluasi dan refleksi.

Teknik pengumpulan data pada penelitian ini yakni: (1) Data tentang aktivitas siswa diambil dengan menggunakan lembar observasi. Keadaan yang diobservasi adalah kegiatan siswa dalam proses pembelajaran dengan penerapan model Problem Based Learning (PBL); (2) Data mengenai motivasi belajar diambil dengan menggunakan angket motivasi belajar pada akhir siklus. Bentuk instrumen yang digunakan adalah angket yang terdiri atas 19 item disertai 5 pilihan jawaban yakni, sangat setuju, setuju, kurang setuju, tidak setuju dan sangat tidak setuju. Sebelum angket di bagikan kepada para siswa terlebih dahulu divalidasi oleh validator ahli dari Centre of Inovation and Development of Biology Department of Makassar State University (CID-BID MSU); (3) Data mengenai peningkatan penguasaan materi diambil dari data tes hasil belajar pada siklus I dan II kemudian membandingkan kedua siklus tersebut.

Data yang telah diperoleh mengenai aktivitas, motivasi dan hasil belajar biologi siswa pada materi sel selanjutnya dianalisis dengan menggunakan cara (1) Aktivitas belajar siswa di analisis dengan menggunakan data pada lembar observasi yang telah diisi oleh 3 orang observer. Cara untuk menghitung presentase aktivitas belajar siswa per kegiatan digunakan rumus dari Satuan Pendidik dan Satuan Pendidikan Sekolah Menengah Atas (2017) sebagai berikut:

$$
\text { Nilai persentase }=\frac{\text { Skor Perolehan }}{\text { Skor maksimal }} \times 100 \%
$$

Kriteria yang digunakan untuk menentukan kategori aktivitas belajar biologi adalah berdasarkan teknik kategorisasi dari Arikunto (2007) sebagai berikut: 
Tabel 1. Pedoman Pengkategorian Keaktivan Siswa

\begin{tabular}{|c|c|}
\hline Interval Nilai & Kategori \\
\hline$>80$ & Sangat Aktif \\
\hline $60-79$ & Aktif \\
\hline $40-59$ & Cukup Aktif \\
\hline $20-39$ & Kurang aktif \\
\hline$>20$ & pasif \\
\hline
\end{tabular}

Motivasi siswa di analisis dengan menggunakan data pada angket motivasi yang telah diisi oleh para siswa. Cara untuk menghitung presentase motivasi belajar siswa digunakan rumus yang diadaptasi dari Sumitro (2017), sebagai berikut:

$$
\text { Persentase motivasi beajar }=\frac{\text { Jumlah skor }}{\text { Skor maksimal }} \times 100 \%
$$

Kriteria yang digunakan untuk menentukan kategori motivasi belajar siswa diadaptasi dari Arikunto dan Safruddin (2014) seperti pada tabel berikut:

Tabel 2. Pedoman Pengkategorian Motivasi Belajar Siswa

\begin{tabular}{|c|c|}
\hline Persentase & Kategori \\
\hline $81-100$ & Sangat Tinggi \\
\hline $61-80$ & Tinggi \\
\hline $41-60$ & Cukup Tinggi \\
\hline $21-40$ & Kurang Tinggi \\
\hline $0-20$ & Sangat kurang \\
\hline
\end{tabular}
berikut:

Hasil belajar menurut Arikunto (2005) dapat dikategorikan seperti seperti pada tabel

Tabel 3. Pengkategorian Tingkat Penguasaan Hasil Belajar

\begin{tabular}{|c|c|}
\hline Interval nilai & Kualifikasi \\
\hline $80-100$ & Sangat baik \\
\hline $66-79$ & Baik \\
\hline $56-65$ & Cukup \\
\hline $40-55$ & Kurang \\
\hline $30-39$ & Gagal \\
\hline
\end{tabular}

Penentuan ketuntasan belajar siswa didasarkan pada kriteria ketuntasan minimal (KKM) untuk mata pelajaran Biologi sesuai dengan yang telah ditetapkan oleh MAN Enrekang.

Tabel 4. Kriteria Ketuntasan Minimal Pelajaran Biologi

\begin{tabular}{|c|c|}
\hline Daya Serap Siswa & $\begin{array}{c}\text { Kategori } \\
\text { Ketuntasan } \\
\text { Belajar }\end{array}$ \\
\hline$<72$ & Tidak Tuntas \\
\hline$\geq 72$ & Tuntas \\
\hline
\end{tabular}

Indikator keberhasilan aktivitas siswa adalah terjadinya peningkatan persentase jumlah siswa yang melakukan setiap komponen aktivitas yang menjadi bahan pengamatan observer 
p-ISSN 2621-5527

e-ISSN 2621-5535
Meningkatkan Aktivitas, Motivasi dan Hasil Belajar Melalui Penerapan Model Problem Based Learning pada Siswa Kelas XI MIPA 1 MAN Enrekang

pada saat proses pembelajaran berlangsung atau persentase jumlah rata-rata dari semua aktivitas siswa telah mencapai $60 \%$ atau minimal pada kategori aktif.

Indikator keberhasilan motivasi siswa adalah terjadinya peningkatan persentase motivasi siswa yang ditandai siswa telah mencapai $61 \%$ atau minimal pada kategori tinggi. Indikator keberhasilan dari segi hasil belajar adalah apabila terjadi peningkatan hasil belajar biologi siswa kelas XI MIPA I MAN Enrekang atau lebih dari 75\% siswa yang tuntas dari nilai KKM yang di tentukan.

\section{Hasil dan Pembahasan}

Hasil analisis deskriptif aktivitas belajar siswa menunjukkan adanya peningkatan peningkatan dari siklus I ke siklus II. Persentase peningkatan aktivitas dapat di lihat pada Tabel 5 .

Tabel 5. Deskripsi aktivitas belajar siswa kelas XI MIPA 1 MAN Enrekang

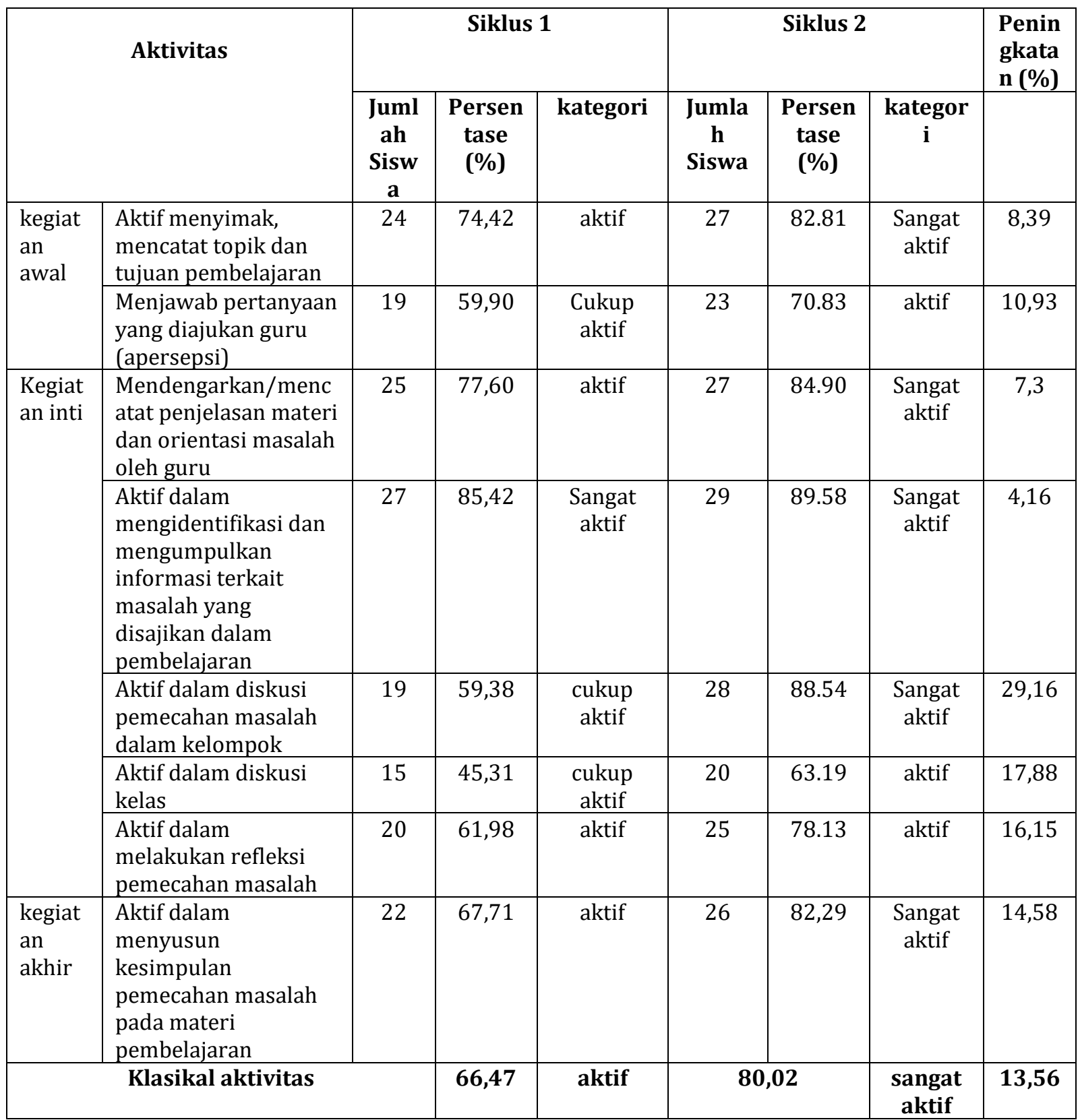


Hasil analisis angket motivasi belajar siswa yang meliputi 5 aspek motivasi pada siklus I mengalami peningkatan pada siklus II. Persentase kenaikan motivasi belajar siswa dapat di amati pada Tabel 6 .

Tabel 6. Persentase Motivasi Belajar Siswa

\begin{tabular}{|l|c|c|c|c|c|c|}
\hline \multicolumn{1}{|c|}{ Aspek } & $\begin{array}{c}\text { Jumlah } \\
\text { soal } \\
\text { angket }\end{array}$ & \multicolumn{2}{|c|}{ Siklus I } & \multicolumn{2}{c|}{ Siklus II } & $\begin{array}{c}\text { Pening } \\
\text { katan } \\
\text { (\%) }\end{array}$ \\
\cline { 2 - 7 } & $\begin{array}{c}\text { Persentase } \\
\text { capaian } \\
\text { (\%) }\end{array}$ & Kriteria & $\begin{array}{c}\text { Persentase } \\
\text { capaian } \\
\text { (\%) }\end{array}$ & Kriteria & \\
\hline $\begin{array}{l}\text { Ketekunan dalam } \\
\text { belajar }\end{array}$ & 5 & 85 & $\begin{array}{c}\text { Sangat } \\
\text { tinggi }\end{array}$ & 88,75 & $\begin{array}{c}\text { Sangat } \\
\text { tinggi }\end{array}$ & 3,75 \\
\hline $\begin{array}{l}\text { Ulet dalam } \\
\text { menghadapi } \\
\text { kesulitan }\end{array}$ & 3 & 87,92 & $\begin{array}{c}\text { Sangat } \\
\text { tinggi }\end{array}$ & 90,63 & $\begin{array}{c}\text { Sangat } \\
\text { tinggi }\end{array}$ & 2,73 \\
\hline $\begin{array}{l}\text { Minat dan } \\
\text { ketajaman } \\
\text { perhatian dalam } \\
\text { belajar }\end{array}$ & 6 & 83,75 & $\begin{array}{c}\text { Sangat } \\
\text { tinggi }\end{array}$ & 88,44 & $\begin{array}{c}\text { Sangat } \\
\text { tinggi }\end{array}$ & 4,69 \\
\hline $\begin{array}{l}\text { Prestasi dalam } \\
\text { belajar }\end{array}$ & 4 & 80,47 & $\begin{array}{c}\text { Sangat } \\
\text { tinggi }\end{array}$ & 87,19 & $\begin{array}{c}\text { Sangat } \\
\text { tinggi }\end{array}$ & 6,72 \\
\hline $\begin{array}{l}\text { Mandiri dalam } \\
\text { belajar sains }\end{array}$ & 4 & 77,19 & tinggi & 79,84 & tinggi & 2,65 \\
\hline \multicolumn{2}{|c|}{ Motivasi klasikal } & $\mathbf{8 2 , 8 7}$ & $\begin{array}{c}\text { Sangat } \\
\text { tinggi }\end{array}$ & $\mathbf{8 6 , 9 7}$ & $\begin{array}{c}\text { Sangat } \\
\text { tinggi }\end{array}$ & $\mathbf{4 , 1 1}$ \\
\hline
\end{tabular}

Hasil analisis yang diperoleh menunjukkan bahwa hasil belajar pada siklus II meningkat dibandingkan hasil belajar pada siklus I. Hasil belajar dapat dilihat pada Tabel 7.

Tabel 7. Distribusi Frekuensi, Persentase dan Kategorisasi Nilai Hasil Belajar Siswa

\begin{tabular}{|c|c|c|c|c|c|}
\hline \multirow{2}{*}{ Interval Nilai } & \multirow{2}{*}{ Kualifikasi } & \multicolumn{2}{|c|}{ Jumlah Siswa } & \multicolumn{2}{c|}{ Persentase (\%) } \\
\cline { 3 - 6 } & & Siklus I & Siklus II & Siklus I & Siklus II \\
\hline $80-100$ & Sangat baik & 12 & 29 & 37,5 & 90,63 \\
\hline $66-79$ & Baik & 16 & 3 & 50 & 9,38 \\
\hline $56-65$ & Cukup & 4 & 0 & 12,5 & 0 \\
\hline $40-55$ & Kurang & 0 & 0 & 0 & 0 \\
\hline $30-39$ & Gagal & 0 & 0 & 0 & 0 \\
\hline
\end{tabular}

Ketuntasan belajar telah mencapai 96,88\%. Hasil ini telah sesuai dengan kriteria ketuntasan belajar yang ditentukan peneliti yaitu $75 \%$ dari keseluruhan siswa di kelas yang telah mencapai nilai $\geq 72$. persentase ketuntasan hasil belajar dapat dilihat pada Tabel 8 .

\section{Tabel 8. Persentase Ketuntasan Hasil Belajar Siswa}

\begin{tabular}{|c|c|c|c|c|c|}
\hline \multirow{2}{*}{ Nilai } & \multirow{2}{*}{ Kriteria } & \multicolumn{2}{|c|}{ Jumlah siswa } & \multicolumn{2}{c|}{ Persentase } \\
\cline { 3 - 6 } & & Siklus I & Siklus II & Siklus I & Siklus II \\
\hline $72-100$ & Tuntas & 19 & 31 & 59,38 & 96,88 \\
\hline $0-71$ & Tidak Tuntas & 13 & 1 & 40,62 & 3,12 \\
\hline
\end{tabular}

Berdasarkan hasil tindakan siklus II yang tersaji pada Tabel 5, 6, 7 dan 8 menunjukkan bahwa tindakan pembelajaran telah mencapai kriteria keberhasilan tindakan. Oleh karena itu, hasil pada siklus II tidak perlu dilanjutkan pada siklus berikutnya. 


\section{Aktivitas Belajar}

Proses pembelajaran dimulai dengan kegiatan awal yang bertujuan untuk mengembangkan pengetahuan awal yang telah ataupun belum dimiliki oleh siswa. Pada kegiatan inti guru mulai mengorientasikan masalah yang berkaitan dengan materi yang akan diberikan melalui tanya jawab, siswa diarahkan kepada masalah-masalah yang ada di lingkungan sekitar siswa kemudian diarahkan kepada masalah yang akan diajarkan. Setelah siswa mulai menyampaikan pendapatnya tentang masalah pembelajaran dan terlihat berdiskusi dengan teman sebangkunya guru melanjutkan pada mengorganisasikan siswa dalam enam kelompok, dua kelompok di antaranya beranggotakan 6 siswa dan 4 kelompok lainnya beranggotakan 5 siswa. Setiap kelompok diberi lembar kerja dan rangkuman materi untuk didiskusikan dengan kelompok masing-masing. Guru membimbing setiap kelompok dalam mengerjakan LKPD dan memberi arahan agar setiap kelompok melakukan presentasi di depan kelas. Ketika kelompok melakukan presentasi guru memberi instruksi agar kelompok yang lain memberikan pendapatnya. Selanjutnya jawaban presentasi kelompok dan pendapat kelompok lain di evaluasi dan diberi penguatan agar seluruh siswa dapat memahami apa yang disampaikan kelompok yang sedang presentasi. Setelah kegiatan presentasi kelompok selesai guru mengajak siswa untuk bersama-sama membuat rangkuman dari apa yang telah dipelajari dan melakukan tanya jawab untuk mengetahui pemahaman siswa terhadap materi yang telah diberikan. Kegiatan akhir guru mengumpulkan lembar kerja siswa dan menyampaikan materi yang akan dipelajari pada pertemuan berikutnya. Pada akhir siklus siswa mengerjakan tes dan mengisi angket motivasi belajar.

Tabel 1 menunjukkan bahwa penggunaan model Problem Based Learning (PBL) dapat mengaktifkan siswa untuk belajar. Hal tersebut ditandai dengan menurunnya jumlah siswa yang kurang aktif dalam kerja kelompok, diskusi kelas, siswa yang melakukan aktivitas lain di luar pembelajaran dan siswa yang tidak mengerjakan tugas dari siklus I ke siklus II.

Kegiatan pembelajaran pada siklus I terlihat bahwa masih banyak siswa yang enggan untuk bertanya, menyampaikan tanggapan dan menjawab pertanyaan pada saat guru menyampaikan materi maupun pada saat diskusi berlangsung. Selain itu terdapat beberapa siswa yang lain ingin menonjolkan diri, umumnya yang terlihat aktif adalah siswa yang pada asalnya tergolong siswa yang cerdas. Sedangkan pada siklus II guru selalu mendorong siswa untuk berbicara dengan memberikan penguatan-penguatan positif. Guru memberikan kesempatan kepada setiap siswa untuk berbicara dalam kelas dengan mengajukan pertanyaanpertanyaan ringan yang sesuai dengan kemampuan siswa yang ditunjuk sehingga siswa merasa lebih termotivasi untuk belajar karena merasa dirinya bisa dalam menjawab pertanyaan yang di berikan oleh guru.

Kekurangaktifan siswa dalam kelas di sebabkan karena siswa masih terpengaruh dengan model pembelajaran yang masih menerapkan sistem kompetisi yaitu pembelajaran yang menerapkan sikap bersaing antarsiswa untuk memperoleh nilai yang lebih baik dari temannya sehingga siswa cenderung menganggap kawan (siswa lain) sebagai lawan. Hal ini terlihat dari sikap siswa yang cenderung mengerjakan tugas tanpa berdiskusi. Sedangkan pada siklus II siswa sudah memahami model pembelajaran yang diterapkan dan dalam diri anggota kelompok telah tertanam rasa saling menghargai satu sama lain serta berkeyakinan bahwa mereka adalah satu tim yang harus saling bekerja sama untuk meraih hasil yang lebih baik secara bersamasama. Hasil penelitian ini menunjang hasil penelitian Magdalena (2016) bahwa tugas yang dikerjakan secara berkelompok akan meningkatkan hasil belajar kognitif siswa atau siswa yang berkemampuan awal rendah dan tinggi, karena melalui tugas kelompok siswa memperoleh pemahaman yang komprehensif dari hasil diskusi dengan teman sebaya.

Proses pembelajaran pada siklus I menunjukkan beberapa siswa terlihat masih belum fokus pada saat kelompok lain sedang melakukan presentasi dan siswa masih tampak bingung dengan bentuk tugas yang diberikan, salah satu kelompok masih berusaha menyelesaikan tugasnya saat kelompok lain melakukan presentasi. Sementara itu, pada siklus II, guru telah 
memastikan bahwa semua kelompok telah menyelesaikan lembar kerja dan siap untuk mengikuti presentasi sehingga pada siklus II siswa lebih fokus dalam belajar. Di bantu dengan pertanyaan-pertanyaan ringan yang di berikan oleh guru terlihat bahwa antusias setiap kelompok dalam memberikan pendapatnya pada saat kelompok lain presentasi menunjukkan perhatian siswa pada pembelajaran yang secara langsung menambah motivasi belajar siswa yang lain. Keller dalam Ocak \& Akcytr (2013) menyatakan bahwa attention atau perhatian merupakan salah satu poin penting dalam menjaga motivasi belajar siswa untuk keberhasilan belajar. Perhatian merupakan alat yang sangat berguna untuk memengaruhi hasil belajar siswa agar menjadi lebih baik.

Proses pembelajaran pada siklus I guru belum menjelaskan manfaat mempelajari materi yang diberikan dalam kehidupan sehari-hari sehingga keterkaitan materi pembelajaran dengan kehidupan nyata belum diketahui siswa. Sementara itu, pada siklus II guru selalu menjelaskan manfaat yang diperoleh setelah mempelajari materi yang diberikan dan mengaitkan materi pembelajaran dengan kehidupan nyata juga peristiwa yang terjadi di lingkungan sekitar siswa. Keterkaitan materi dengan lingkungan sekitar siswa diharapkan dapat menumbuhkan motivasi belajar dari dalam diri siswa karena siswa merasa bahwa materi pelajaran yang diberikan mempunyai manfaat langsung secara pribadi dalam kehidupan sehari-harinya. Menurut Sanjaya (2013), minat siswa akan tumbuh manakala ia dapat menangkap bahwa materi itu berguna untuk kehidupannya.

Proses pembelajaran pada siklus I saat presentasi siswa masih tampak terlihat kurang percaya diri dan merasa malu karena belum terbiasa mengungkapkan pendapatnya di depan kelas. Namun, karena guru selalu memberikan penguatan positif, rasa percaya diri, dan sikap optimis siswa semakin tampak terutama pada siklus II. Rasa percaya diri siswa tampak ketika siswa mengemukakan pendapat dan mengajukan pertanyaan serta kegiatan presentasi. Dalam proses pembelajaran guru meminta setiap siswa dalam kelompok untuk naik mempresentasikan hasil kerjanya. Siswa memiliki antusias yang tinggi, dengan percaya diri maju untuk presentasi tanpa ditunjuk. Mendukung hasil penelitian Magdalena (2016) bahwa kegiatan saling belajar bisa terjadi apabila tidak ada pihak yang dominan dalam komunikasi, tidak ada pihak yang merasa segan untuk bertanya, tidak ada pihak yang menganggap paling tahu, semua pihak mau saling mendengarkan. Setiap pihak harus merasa bahwa setiap orang lain memiliki pengetahuan, pengalaman, atau keterampilan yang berbeda yang perlu dipelajari.

\section{Motivasi Belajar}

Data hasil angket motivasi siklus I menyatakan bahwa secara klasikal motivasi siswa dalam belajar dengan penerapan model problem-based learning berada pada kategori sangat tinggi, setiap aspek yang di amati sebagian besar menyatakan motivasi yang sangat tinggi kecuali pada aspek mandiri dalam belajar sains berada pada kategori tinggi. Ini menunjukkan bahwa dalam belajar siswa membutuhkan guru atau teman dalam membantu mereka untuk mencapai tujuan belajarnya. Meskipun demikian presentase motivasi belajar siswa pada siklus I telah menunjukkan tercapainya indikator keberhasilan yaitu motivasi siswa mencapai minimal pada kategori tinggi.

Motivasi peserta didik dapat mempengaruhi tingkat keberhasilan atau kegagalan belajar dan umumnya belajar tanpa motivasi akan sulit untuk berhasil. Oleh sebab itu, pembelajaran harus disesuaikan dengan kebutuhan, dorongan, motif, minat yang dimiliki peserta didik.

Penggunaan motivasi dalam mengajar bukan hanya melengkapi elemen pembelajaran, tetapi juga merupakan faktor yang menentukan pembelajaran efektif. Bebarapa penelitian tentang prestasi belajar menunjukkan bahwa motivasi merupakan faktor yang banyak memberikan pengaruh terhadap proses dan hasil belajar. 
Pelaksanaan pembelajaran biologi dengan menerapkan model problem-based learning dapat memberikan dorongan atau motivasi belajar siswa karena muatan materi pembelajaran biologi kaya akan permasalahan yang sesuai dengan kehidupan nyata dialam sekitar. Hamalik (2013) menyatakan bahwa motivasi siswa akan bangkit dan berkembang apabila mereka merasakan bahwa apa yang dipelajari itu memenuhi kebutuhan pribadi, bermanfaat serta sesuai nilai yang diyakini dan dipegangnya.

\section{Hasil Belajar}

Aktivitas dan motivasi belajar siswa yang tinggi akan membuat siswa semangat dalam belajar serta mampu menciptakan suasana yang kondusif dan interaktif dalam proses belajar mengajar. Hal tersebut dapat mendorong siswa untuk belajar dan memperoleh hasil belajar yang baik. Selain itu peningkatan hasil belajar biologi terjadi karena penerapan model Problem Based Learning. Hal ini dilihat dari hasil belajar siswa meningkat pada setiap siklus yang dilakukan. Peningkatan hasil belajar siswa dari siklus I ke siklus II dapat dilihat pada jumlah persentase ketuntasan hasil belajar siswa pada siklus I sebesar 59,38\% meningkat pada siklus II menjadi $96,88 \%$.

Ketuntasan hasil belajar secara klasikal pada siklus I sebesar 59,38\% masih perlu upaya perbaikan pada siklus berikutnya karena belum mencapai kriteria ketuntasan belajar yang ditentukan peneliti yaitu $75 \%$ dari keseluruhan siswa dikelas yang telah mencapai nilai $\geq 72$. Masih terdapat 13 siswa yang belum tuntas dari jumlah siswa sebanyak 32 orang. Belum tuntasnya hasil belajar siswa disebabkan karena siswa tersebut belum menguasai konsep yang dipelajari, tampak saat evaluasi akhir siklus I ditemukan siswa yang bertanya pada temannya. Beberapa siswa kurang percaya diri akan kemampuan sendiri dalam menyelesaikan soal evaluasi siklus I. Dengan demikian, kualitas pembelajaran pada siklus II perlu ditingkatkan agar siswa mampu menguasai konsep pembelajaran dengan lebih baik.

Perbaikan yang dilakukan pada siklus II menunjukkan adanya peningkatan hasil belajar siswa. Jumlah siswa tuntas belajar meningkat menjadi 31 orang, sedangkan 1 siswa belum tuntas belajar dengan persentase hasil belajar secara klasikal sebesar 96,88\%. Hasil ini telah sesuai dengan kriteria ketuntasan belajar yang ditentukan peneliti yaitu $>75 \%$ dari keseluruhan siswa dikelas yang telah mencapai nilai $\geq 72$. Menurut Sanjaya (2013) bahwa masing-masing individu dapat mengembangkan pengetahuan sendiri dalam struktur kognitif yang dimilikinya. Guru mengarahkan pada usaha menciptakan lingkungan belajar yang mampu mendorong perkembangan kognitif siswa.

\section{Kesimpulan}

Berdasarkan hasil penelitian dan pembahasan di atas, maka dapat disimpulkan bahwa (1) Penerapan model Problem Based Learning (PBL) dapat meningkatkan aktivitas belajar biologi siswa kelas XI MIPA 1 MAN Enrekang, yaitu secara klasikal dari 66,47\% meningkat menjadi 80,03\%, jumlah peningkatan dari siklus I ke siklus II adalah 13,56\%. (2) Penerapan model Problem Based Learning (PBL) dapat meningkatkan motivasi belajar biologi siswa kelas XI MIPA 1 MAN Enrekang, yaitu secara klasikal dari 82,87\% meningkat menjadi 86,97\%, jumlah peningkatan dari siklus I ke siklus II adalah 4,11\%. (3) Penerapan model Problem Based Learning (PBL) dapat meningkatkan hasil belajar biologi siswa kelas XI MIPA 1 MAN Enrekang, yaitu dari 59,38\% siswa yang tuntas menjadi $96,88 \%$, jumlah peningkatan dari siklus I ke siklus II adalah $37,50 \%$. 


\section{Referensi}

Amrullah, A. (2016). Pengaruh Model Pembelajaran Proble Based Learning Terhadap Hasil Belajar Biologi Siswa pada Konsep Fungi. Skripsi. Program Studi Pendidikan Biologi, Jurusan Pendidikan Ilmu Pengetahuan Alam, Fakultas Ilmu Tarbiyah dan Keguruan, Universitas Islam Negeri Syarif Hidayatullah Jakarta

Arikunto, S. (2005). Dasar-dasar Evaluasi Pendidikan. Jakarta. Bumi Aksara.

Daoed, J. (2009). Pembodohan Siswa Tersistematis. Cetakan III, Jakarta. Pinus.

Hamalik, O. (2013.) Proses Belajar Mengajar. Jakarta. PT. Bumi Aksara.

Magnalena, R. (2016). Penerapan Model Pembelajaran Problem Based Learning (PBL)serta Pengaruhnya terhadap Hasil Belajar Biologi Siswa SMA Negeri 5 Kelas XI Kota Samarinda Tahun Ajaran 2015. Proceeding Biology Education Conference. 3 (1).

Muslich, M. (2007). Pembelajaran Berbasis Kompetensi dan Kontekstual. Jakarta. PT Bumi Angkasa

Musriadi, D. \& Muhibbudin. (2014). Penerapan Pembelajaran Berbasis Masalah terhadap Peningkatan Hasil Belajar Biologi Siswa SMA Inshafuddin Banda Aceh. Jurnal EduBio Tropika. 2(1).

Suprijono, A. (2012). Cooperative Learning: Teori dan Aplikasi Paikem. Yogyakrta. Pustaka Pelajar.

Syah, M. (2010). Psikologi Pendidikan dengan Pendekatan Baru. Bandung. PT Remaja Rosdakarya, Cet. 15

Syah, M. (2013). Psikologi Pendidikan dengan Pendekatan Baru. Bandung. PT Remaja Rosdakarya, Cet. 182013.

Trianto. (2010). Mendesain Model Pembelajaran Inovatif-Progresif; Konsep, Landasan, dan Implementasinya pada Kurikulum Tingkat Satuan Pendidikan. Jakarta. Kencana, Ed. 1, Cet. 2.

Undang-Undang Dasar Tahun 1945 Pasal 31 ayat 1 tentang pendidikan dan kebudayaan

\begin{tabular}{|c|c|}
\hline Nurfadillah & $\begin{array}{l}\text { S.Pd. Jurusan Biologi. Fakultas Matematika dan Ilmu } \\
\text { Pengetahuan Alam, Universitas Negeri Makassar } \\
\text { E-mail: nurfadillahbio@gmail.com }\end{array}$ \\
\hline Mushawwir Taiyeb & $\begin{array}{l}\text { M.Kes, Dr. Dosen Jurusan Biologi. Fakultas Matematika dan Ilmu } \\
\text { Pengetahuan Alam, Universitas Negeri Makassar } \\
\text { E-mail: mtaiyeb333@gmail.com }\end{array}$ \\
\hline Syamsiah & $\begin{array}{l}\text { M.Si, Dr. Dr. Dosen Jurusan Biologi. Fakultas Matematika dan } \\
\text { Ilmu Pengetahuan Alam, Universitas Negeri Makassar } \\
\text { E-mail: syamsiah.msi@gmail.com }\end{array}$ \\
\hline
\end{tabular}

